\title{
Resolving meaning conflict in translation: An optimality approach to verse translation
}

\author{
Nicolau Dols \\ Universitat de les Illes Balears ${ }^{1}$ \\ Richard Mansell \\ University of Exeter ${ }^{2}$
}

This article proposes an application of Optimality Theory (Prince and Smolensky 1993) to translation analysis, suggesting that the translation process is regulated by a hierarchy of universal yet violable constraints. The constraints are always present but in conflict: strategies are determined by their hierarchy, and a constraint can be violated but only to avoid violation of a more highly-ranked constraint, i.e. a prioritised form of transfer. Optimalist concepts present in the literature are surveyed, and after a series of examples the authors propose that an optimalist approach reveals translators' strategies and their basis both at a micro- and textual level, a theoretical basis for a multi-layer unit of translation, a cognitive basis for Toury's two laws of translation, and they suggest that there are no others.

\section{Introduction}

One of the best founded principles in modern linguistics, sign arbitrariness was once put at the top of a hierarchy of statements by one of Saussure's students. ${ }^{3}$ It remains clear that sign arbitrariness underlies the main problem in translation, i.e., what equivalence (as a textual relationship) stands for and in which ways it is measurable. This article aims to approach both the definition and measurement of equivalence between source and target texts (ST and TT) by means of an application of Optimality Theory to the decision-making process in translation, and subsequently to discover whether any 'hierarchy of truths', or prioritisation of features, can shed light on problems arising from verse translation. As part of the application, this article also aims to provide useful insights into the basis of the unit of translation and the nature of so-called laws of translation, as found in Toury (1995).

\section{Optimality Theory}

OT appeared for the first time in Prince and Smolensky (1993/2002) and in McCarthy \& Prince (1993) ${ }^{4}$ and it is not difficult to find sound accounts of Optimality Theory in phonology (Kager 1999) and, more generally, in grammar (Boersma, Dekkers \& van de Weijer 2000). The first advantage of 
the theory was to combine the universal and the specific in linguistics in a frame pointing at constraint violations as the cause of cross-linguistic differences: in OT, language is governed by two basic universal constraint families (faithfulness and markedness) which determine that underlying lexical forms and observed surface forms match, and that the latter should be structurally well-formed. Together with other constraints they constitute a constraint ranking which is language-specific. Some constraints are violated in order to satisfy a higher-ranked constraint. So, languages violate more easily those constraints ranking low in their constraint hierarchies. As a result, computing the quantity and quality of constraints can help the linguist to elucidate language-specific rankings. Secondly, no intermediate, unseen levels of representation were needed anymore: the theoretical frame expounded by Chomsky \& Halle (1968) worked in a sequential fashion changing sound chains step by step by applying phonological rules in a given order, yet only phonetic representation (what we actually hear) was physically known. On the other hand, the morphonological underlying (i.e. not physically accessible) representation was the result of transformational rules applying to the syntactic underlying representation, which meant that phonology started where syntax finished. As a result, all possible stages between morphonological underlying representation and phonetic representation were postulated, increasing the complexity of the system, and structure was added only for the sake of explanation. However, keeping underlying and phonetic representations different is usually a way of gaining economy in grammar: if morphonetic processes are regular and predictable, there is no need to add complexity to lexical units, or, in other words, once you state a process you need not keep two instances of the same unit as different entities in your lexicon. OT solved the problem of maintaining the differences between underlying and phonetic representations without a rule-based derivation system by calling in the socalled Gen(eration) function. By this, all possible candidates to become output representations of a given input are created. A second function, now called Eval(uation) selects the optimal candidate in every case. The optimal candidate is always the one with the lowest-ranking constraint violations, and language-particular hierarchies of universal constraints explain how Eval works. The point for the linguist is that examining winning candidates against other candidates, the particular constraint hierarchy of a given language can be pointed out.

\section{Focusing on translation}

Let us work now on several assumptions relating to (verse) translation:

1. Sign arbitrariness makes it impossible for a translation to be fully identical to the ST. As a result, either:

a. Translating is impossible; or

b. An element of difference is inherent to translation. 
2. Texts are multidimensional entities, and so any difference may exist on various and multiple levels.

3. If $1 \mathrm{~b}$ and 2 are true, then there are different ways in which two acceptable translations can differ from the ST

a. Differences between two translations of the same source can be analysed on the grounds of conflicting priorities (constraints in our terminology).

b. Constraint hierarchies reflect translators' preferences.

(1) above is an axiom firmly founded in linguistics. (1a) has already been discussed in literature 5 and it is not our intention to present new arguments, other than the fact that translation happens. Instead, (1b) allows us to connect with other more possibilistic views on translation rooted in concepts such as 'negotiation', ${ }^{6}$ or plainly 'optimality' ${ }^{7}$ Pending from (1b), (3) opens the door to a method well proven in linguistics and heads through (3b) to a new way of classifying translations aloof from rigid typologies. In this article we shall focus on crucial facts that affect the analysis of verse translation and range from (1b) to (3b) above.

\section{Precedents of optimality in translation studies}

One reason why Optimality Theory became so popular so quickly consider, for instance Boersma, Dekkers and van de Weijer's description of OT as 'the single most important development of generative grammar in the 1990s' (2000: 1) - was because the notion of optimality and constraint interaction had been underlying in the literature for a long time (Speas 1997: 171). We believe that there is a parallel in translation theory, and that rather than turn translation theory on its head, an application of Optimality Theory can in fact consolidate much work done in translation studies and give a theoretical basis to many statements and concepts in the field (see the discussion of Toury's laws below), as well as aid in the dismissal of arbitrary concepts.

\subsection{Translation as a decision-making process, compromise and negotiation}

Pym describes translational competence as the ability to create a series of candidate translations for a stretch of text and then choose a TT quickly and justifiably from these (Pym 1992). This shares the same basic view as an approach based on Optimality Theory (the chosen translation would be optimal), although Pym does not suggest how the decision is made. Chesterman develops Pym's theory (Chesterman 1997: 120) and suggests that the decisions are made by means of a series of 'strategies'. These, however, are drawn fairly uncritically from Vinay and Darbelnet's comparative stylistics, and as such are open to the same criticism: amongst 
other things, that they are labels applied to the products of translation, and not descriptions of the translator's state of mind when entering into the process and during the process of translation (Mason 1994). Just as in Vinay and Darbelnet, none explain why a particular choice is taken. Process-oriented research, due to its very nature, has provided insights into the discarded options in the translation process, and Tirkkonen-Condit has proposed a 'literal translation automaton', which is 'the default procedure resorted to as long as it satisfies the equivalence criterion' (2005: 408). Although this 'equivalence criterion' is not made explicit, we can assume that it is the criterion set by the translator him or herself, and by extension the criterion demanded by the context of the process - which in turn needs defining. Not only can OT propose an explanation for the automaton (the preponderance of faithfulness) it can also aid in defining the equivalence criterion - the constraint hierarchy in a particular context. Consequently, the action of the 'literal translation automaton' at lower levels can be identified.

If translation is a decision-making process, then it is also about compromise: the translator must decide what can be represented and what can be omitted. Schleiermacher expelled negotiation from translation proper (Pym 2004: 155), but it is impossible to represent all features of the ST at once, and so some choices must be made: whether this concept is called decision making or negotiation, the evaluation of candidates is in fact central to the task of the translator. This is clear from the theory and also practitioners' comments on their activity, such as Bly (1984). In this piece, the poet-translator comments on four possible English translations of the same two lines from Rilke in arbitrary terms, and despite the fact he justifies one choice with the phrase 'My ear feels better now' (Bly 1984: 76), the concept of a candidate set and its assessment is present.

Gutt (2000) and Holmes, in their approaches to decision making, both refer to the work of Levý. Holmes in particular states that:

[The] activity of confrontation and resolution is, as the late Jirrí Levý pointed out, an elaborate process of decision-making, in which every decision taken governs to some extent the nature of all decisions still to be taken. (Holmes 1988[1969]: 11)

This could describe the translation process as conceived in optimality terms: all decisions are linked, since the choice of one section of candidate TT conditions the possibilities of further candidate sections. In approaching translation as a decision-making process, this thesis coincides with Levý, although his approach considers that there is a 'certain (and very often exactly definable) number of alternatives' (Levý 2000[1967]: 148). He proceeds to give the example: of the 'choices' for translating the German word Bursche include 'boy, fellow, chap, youngster, lad, guy, lark, etc.' (Levý 2000[1967]: 150). For Levý, the propositional meaning of 'a young man' is the 'definitional instruction' for the translator, and 'selective 
instructions' govern the available possibilities. So, this example does not include the perfectly viable translation strategies of deletion and addition, which then open up many other possible choices. With these Levý's definable number of alternatives becomes greater, and with that less definable. Ultimately, the key problem is not how great this number of alternatives can be: it is that the idea of a definable number of alternatives comes from a source-driven approach to translation, which is in fact a derivative approach to translation. In this approach it is the ST, and only the ST, that can give rise to possible translations: the role of the target system is not taken into account. We suspect that from a descriptive point of view, the number of alternatives is not definable: it is infinite.

Gutt assesses the 'problem of evaluation and decision-making' (Gutt 2000: 7-17) and laments that many models, although referring to decision making, do not follow this observation through to its logical conclusions: some, such as Newmark, even deny 'that this aspect of translating should or could be covered from a theoretical point of view' (Gutt 2000: 9). Some go into so much detail that equivalence-based studies 'cannot possibly be integrated in a general translation theory' (Wilss 1982: 135, in Gutt 2000: 11) and defeat the object of a theory of translation, which is to describe 'complex phenomena in terms of simpler ones' (Gutt 2000: 11). Gutt's main complaint, however, is that many approaches do not 'explicate how the translator is to make the decisions necessary in the translation process; this is left to expert intuition' (Gutt 2000: 19). Gutt uses Relevance Theory to attempt to explain this, and the role of context is key (as it always is in translation), although this is not context in the traditional sense of the text immediately surrounding another text, or an encyclopaedia of cultural factors. In Relevance Theory, context is a psychological construct that 'refers to part of their [the people involved in communication] "assumptions about the world", or cognitive environment as it is called" (Gutt 2000: 27; italics in original).

Relevance itself is not a concept based on the transfer of information, but rather on information processing (Sperber and Wilson 1995: 49), and so individuals, and particularly the listener/reader are key in understanding, since it is precisely the listener/reader who creates meaning from an utterance. Essentially, the relevance principle dictates that an individual requires maximum reward for minimum effort, and so in translation targetaudience considerations will be at the forefront of the translator's mind. Yet it is precisely the preponderance given to the target audience that is a basic methodological issue with Gutt's approach, exemplified in the statement that '[W]hatever decision the translator reaches is based on his intuitions or beliefs about what is relevant to his audience' (Gutt 2000: 118). With this proposal, translation is restricted to being translation for communication's sake since (for this approach) all translation aims to be successful communication, even though it may not achieve this success. Yet this does not take account of phenomena such as the Zukofskys' phonemic translation of Catullus, where faithfulness to ST phonemes is a priority. In 
such cases, target audience considerations have very little to do with a translation whose guiding principle is rank-bound equivalence at the level of phonemes. ${ }^{8}$ To say that the Zukofskys translated in such a manner because they considered it was relevant to their audience, whereas a representation of semantic features was not, tells us nothing about the decision-making process itself: we return to the realms of a label placed on the final product, a label bearing the title 'hopefully relevant to an audience'.

The importance of considering what was not done, as well as what was, is highlighted by Pym, both in the sense of other possible translations (Pym 2004: 23-25) and absence of translation (either importing the ST wholesale into the target locale, or no transfer at all, that is neither importing nor translating the text) (Pym 2004: 26). This is key in Optimality Theory: if the text is to be translated, then the process begins in earnest and the conflict between faithfulness and markedness must be resolved.

It is our belief that decisions are made based on a hierarchy of demands. In Optimality Theory, there are no rules to be applied to inputs to create candidate outputs, and so it 'shifts the burden from the theory of operations (Gen) to the theory of well-formedness (H-eval)' (Prince and Smolensky 2002[1993]: 5). Thus the role of the constraint hierarchy, in its role as assessment criteria for the candidate set, is key in determining optimal outputs: in principle, the generator function can propose anything as a candidate output.

House is clear that 'the translator must set up a hierarchy of demands on equivalence which he wants to follow' (House 2001: 135), although for House equivalence is purely a functional-pragmatic concept to which the translator should conform: nothing is said about how translators should make their decisions to conform to this concept, merely that they should conform to it.

\subsection{Translation as relations}

The idea of translation as relations and resemblance is a recurrent one in the literature. This is perhaps strongest in Holmes, who claims that different ways of translating, as well as critical essays on a poem and poems based on a poem, are all linked by Wittgensteinian family resemblances, and verse translation is unique since it is where interpretation and expression overlap (1988b[1969]: 24). Koster, too, refers to translation as a double bind between source and target, and between the target text and the system welcoming it (2000: 42). Optimality Theory represents this by means of the constraint hierarchy: on the one hand, the interaction of faithfulness and markedness explains the interaction of interpretation and expression inherent to translation; on the other, the more similar two constraint hierarchies are, the stronger the family resemblance between two strategies or styles of translation, whilst individual relations are represented by 
individual constraints. Indeed, Optimality Theory is often seen as a theory of relations (McCarthy 2000: 151). Frank, too, refers to relations between an ST and TT when revisiting Holmes' typology of verse translation schema, stating that assumptions 'can be verified by examining relations' (Frank 1991: 126). An approach based on Optimality Theory would give these relations a theoretical basis.

\subsection{Translation product as optimal}

Another cornerstone of the Optimality Theory approach is that the translation produced is the best possible translation in the circumstances: thus the aim of analysis is to reveal what the translator has done, and what these circumstances were. This approach finds an echo in Frank, who posits 'the notion that the particular translation he [a translator] has produced is the best possible translation under the conditions that have prevailed' (Frank 1991: 121). As we have already seen, this is also the opinion of Pym, who even posits constraints on the process, such as time and confidence in abilities. Note, though, that this does not mean that an optimal translation cannot be bettered, merely that it is a product of its own context, which includes the ability of the translator, and also translators' willingness to exert themselves: thus this theory allows for change over time, and takes into account the context of translation. ${ }^{9}$

\subsection{Two or more texts received as acceptable translations of the same source text}

Ke's argument is self explanatory (1999, as cited in Song 2005). We shall just introduce the main evidence to be analysed in this article as an instantiation of Ke's argument. As an example, we can take the following six lines from different poems written in Catalan:

(1) perquè la rosa de beutat no mori ['so that the rose's beauty does not die']

(2) per a la flor de la beutat servar ['in order to grasp beauty's rose']

(3) que la bellesa en flor mai no pugui morir ['that beauty as a flower may never die']

(4) perquè la rosa de l'encant no mori ['so that the enchanting rose does not die']

(5) perquè no mori mai l'esplendor de la rosa ['so that the rose's splendour never dies']

(6) perquè així no mori mai la bellesa de la rosa ['so that in this way the rose's beauty never dies'] 
They are all different ways in which the second line of Shakespeare's sonnet number 1, 'That thereby beauty's rose might never die', has been translated into Catalan. ${ }^{10}$ What seems important to us is not the fact that any of these translations has been actually accepted as a line in Catalan corresponding to Shakespeare's original, but that divergences among TTs appear to run along different dimensions or vectors. Differences in rhythm, syntax and semantics combine in different ways to produce the lines cited. Just to point out a couple of examples, (1) shows a verb in a personal form while (2) is built upon an infinitive and (3) on a verbal periphrasis ;(3) and (5) are alexandrines of two hexasyllabic hemistichs while (1), (2), and (4) are decasyllables, and (6) an irregular verse; (2) and (3) prefer the hyperonym flor 'flower' to rosa 'rose'; (1), (2) and (4) use 'flower' as the nucleus of the noun clause while (3), (5) and (6) prefer to leave the flower or the rose in the prepositional clause tied to the nuclear splendour or beauty, etc. Combining divergences in different vectors complicate the comparisons even more . Moreover, the relation between those lines cited here with the rest of the translated poem in eech case increase complexity in the fields of content/verse alignment or rhyme structure.

Let us not forget that all of these translations exist in published form and thus have at a certain point been accepted by publishers and readers as equivalent to 'That thereby beauty's rose might never die'. The empiricist point of view regarding translation as consummated facts is safeguarded here. However, popular ideas on translation are challenged by such a rich 'florescence'. The point of the comparison is not only to establish a taxonomy, but more importantly to get to the genesis of translation. For this purpose we shall assume that translating (poetry) is not just an impressionistic activity, but the result of organizing the translator's preferences. A formal apparatus for analysing conflicting constraints in the translation of poetry is proposed in the following section.

\section{Analysing conflicting constraints in verse translation}

Broadly speaking, three vectors can be readily identified when comparing poetry translations: content, syntax and verse. Although the range of dimensions can be increased (for instance the dimension of rhetorical figures) these three will suffice for our purposes here. Moreover, the identification of dimensions is not the sole consideration, but also the direction of divergences along those dimensions. In each case, options tend to be loyal to the ST or obedient to a concept of the language and literary tradition to which the TT aims to belong.

Our position is that translators aim for a specific point on a continuum between fidelity to the ST or fidelity to target grammar and literary tradition. Moreover, the three dimensions cited are not treated in the same way: for instance, fidelity to content can be sacrificed for the sake of fidelity to either source or target grammar and vice versa, among many 
other combination of options. Fidelity to both sides of the operation in each vector is extremely difficult to achieve. ${ }^{11}$ However, constraints on translation requiring such a degree of matching between texts can be thought of as active at the top of the translator's principle hierarchy at the start of the operation. Only when the aim proves to be unreachable, are certain specific constraints demoted to a lower level in the hierarchy. Let us now try to identify the two basic constraint families of faithfulness and markedness.

\subsection{Faithfulness constraints}

\subsection{F/CONTENT ${ }^{12}$}

The series of translations below will exemplify how OT faithfulness constraints, where output can be read as target text and input as source text, also apply to the translation process.

ID: an element in output corresponding to an element in input must be identical to the input element.

MAX: all elements in input must have a correspondent in output.

DEP: all elements in output must have a correspondent in input. ${ }^{13}$

In the first example the translator adheres in such a way to the original metre (also shared by the target literary tradition), i.e., Metre and F/Metre are so highly ranked in the translator's hierarchy, that previously nonexistent content is added and Dep, i.e. "do not add previously non-existent content", is violated in order to give a line a syllable length respecting both the source line and the target verse tradition. Observe how "ulls benignes" does not translate anything from the source poem:

(1a) Claros olhos azúis, olhos formosos, que o lume destes meus escurecestes, olhos que o mesmo Amor de amor vencestes, com vivos raios sempre vitoriosos. (Fernando Rodrigues Lobo Soropita, lines 1-4)

[You clear blue eyes, beautiful eyes, that darkened the light of my own, you eyes that vanquished the very love of love, with vivid and ever victorious rays.]

(1b) Clars ulls blaus, ulls benignes, ulls formosos, que la llum d'aquests meus en nit desféreu, ulls que el mateix amor d'amor vencéreu amb vívids raigs tostemps victoriosos. (tr. Joan Alegret) 
[You clear blue eyes, kind eyes, beautiful eyes, that undid the light of my own into night, you eyes that vanquished the very love of love, with vivid and ever victorious rays.]

In a similar fashion, the last two lines of 'Futility', by Wilfred Owen, are accommodated by Marià Manent into two alexandrines, where the ST produces an octosyllabic line and a hexasyllabic line. The translator's metric frame forces the addition of new content. The difference with the previous example is the relative place of F/Metre in the hierarchy, placed now beneath Metre in the same level as Dep (Metre >> Dep, F/Metre).

-O what made fatuous sunbeams toil

To break earth's sleep at all? (Wilfred Owen, lines 7-8)

(2b) ¿Per què maldaven, fatus, els raigs de sol, antany, i trencaven el son de la terra tranquil·la? (tr. Marià Manent, lines 78)

[Why did they struggle, fatuous, the sun's rays, long ago, and break the sleep of the tranquil earth?]

Sticking to metre can force, as we have seen, divergence in content quantity. Content quality can also be challenged when synonymy is taken too far. This is expected to occur when either (or both) Metre or F/Metre climbs above Id (for identity, which stands for "relation between two lexical items from different languages with a maximum of correspondence in meaning in a given context"):

(3a) Mon cor estima un arbre! Més vell que l'olivera, més poderós que el roure, més verd que el taronger, conserva de ses fulles l'eterna primavera, i lluita amb les ventades que atupen la ribera com un gegant guerrer. (Miquel Costa i Llobera, 'El pi de Formentor', lines 1-5)

[My heart loves a tree! Older than the olive, more powerful than the oak, greener than the orange, in its leaves it keeps the eternal spring, and it struggles with the gusts that beat the shore like a warrior giant.]

(3b) Hay en mi tierra un árbol que el corazón venera: de cedro es su ramaje, de césped su verdor; anida entre sus hojas perenne primavera, $\mathrm{y}$ arrostra los turbiones que azotan la ribera, 
añoso luchador. (tr. Miquel Costa i Llobera, lines 1-5)

[In my land there is a tree that hearts revere:

its branches are like cedarwood, its green like a lawn;

perennial spring nests amongst its leaves,

and it confronts the deluges that lash the shore,

aged fighter.]

Leaving aside syntax and content quantity, cedro, césped and añoso stand for referents unidentifiable with those of ST roure, taronger and gegant.

Opposite to the effect caused by a relatively low position of DEP in the hierarchy, weakness of MAX (i.e., "do not erase source content") can result in parts of the content being left behind, as in these lines of the Spanish translation of Browning's Sonnets from the Portuguese:

(4a) I thought once how Theocritus had sung

Of the sweet years, the dear and wished for years,

Who each one in a gracious hand appears

To bear a gift for mortals, old or young. (Elizabeth Barrett Browning, lines 1-4)

(4b) Releía los dulces versos de Teócrito

sobre los dulces años que tendían

con mano generosa a los mortales

un don, ya fueran jóvenes o viejos. (tr. Carlos Pujol, lines 1-4)

[I re-read Theocritus' sweet verses

on the sweet years, which offered

with a generous hand to mortals

a gift, whether they were old or young.]

The 'dear and wished for years' and 'each one' have been lost in the TT, non-rhyming but rhythm-constrained to ten syllables. Respect for maximum length has forced the translator to understand both phrases as redundant in the ST.

\subsubsection{F/GRAMMAR}

Similarly, the translation process may be characterized by faithfulness constraints that apply at the level of grammar.

ORD: language specific grammar allowing, all elements in output must appear in the same order as in input.

SYN: syntactic relations in input must be preserved in output. 
Both constraints are exemplified in examples 5 and 6 respectively. Dylan Thomas's "And death shall have no dominion" ends in a stanza where a concessive sense can be perceived in the facts announced, whereas no concessive clause is present. Villangómez translates this piece on a basis of decasyllables, alexandrines and longer verses based on decasyllables and hexa- or octosyllabic hemistichs. His adherence to metre may be seen as the cause for the syntactic structure chosen, which violates faith to the ST syntactic structure. It must be noticed that a literal translation showing the same syntactic structure underlying the ST would be fully accepted in Catalan, although would not meet requirements of metre:

And death shall have no dominion.

No more may gulls cry at their ears

Or waves break loud on the seashores;

Where blew a flower may a flower no more

Lift its head to the blows of the rain;

Though they be mad and dead as nails,

Heads of the characters hammer through daisies;

Break in the sun till the sun breaks down,

And death shall have no dominion. (lines 1-9)

(5b) I la mort no tindrà cap senyoriu.

Encara que mai més les gavines no els cridin a l'orella

o les ones no es rompin amb soroll a les ribes,

malgrat que on va brotar una flor mai més una altra flor

no aixequi el front als embats de la pluja;

tot i que estiguin folls i morts com claus,

els caps dels personatges a cops s'obriran pas entre les margarides;

dominaran el sol fins que el sol caigui,

i la mort no tindrà cap senyoriu. (lines 1-9)

[And death will have no lordship.

Even if gulls never again cry at their ears or waves do not break noisily on the shores, even though where a flower blossomed another flower never again raises its brow to the beating of the rain;

even though they are mad or dead as nails, the heads of characters will beat a path amongst the daisies; the will master the sun until the sun falls, and death will have no lordship.]

The first lines of Rupert Brooke's "The great lover" are translated into Catalan by Campillo, who places elements in a different order:

(6a) I have been so great a lover: filled my days So proudly with the splendour of Love's praise, 
The pain, the calm, and the astonishment, Desire illimitable, and still content,

And all dear names men use, to cheat despair, For the perplexed and viewless streams that bear Our hearts at random down the dark of life.

(6b) He estat un amant tan magnífic: [amb les delícies de l'elogi a l'amor $]_{1}[\text { vaig omplir }]_{2}[\tan \text { orgullosament }]_{3}[$ els meus dies $]_{4}$ amb el dolor, la calma, l'emoció, el desig il-limitable i tanmateix tranquil $i$ tots els noms preciosos que, [per enganyar el desesper] $]_{5}$, [empren els homes $]_{6}$ per designar els corrents confusos i soterrats que s'enduen

els nostres cors a l'atzar, cap a la banda fosca de la vida. (lines 1-7)

[I have been such a magnificent lover: with the delights

of the praise of love I filled so proudly my days

with the pain, the calm, the emotion,

the illimitable and yet tranquil desire

and all the beautiful names that, to deceive despair,

men use to name the confused and underground currents that carry our hearts at random to the dark side of life.]

Brooke's text presents elements 1, 2, 3 and 4 in the order as 2-4-3-1, which is in fact a correct order in Catalan; it is even an unmarked grammatical order. Changes of the source order, not caused by any grammatical rule in the target language, must be seen (since no other constraint can be invoked) as a stylistic choice on the part of the translator. The same can be said for the reordering shown by elements 5 and 6 . On the other hand, the differences in order between Campillo's '[l'elogi $]_{1}$ [a l'amor $]_{2}$ ' and

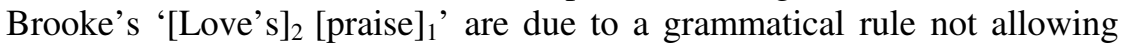
order to be altered. For this reason this case of change in order cannot be taken into account.

\subsubsection{F/Verse}

At verse level, too, faithfulness constraints can be observed in translation. They are:

F/METRE: verse metre in output must respect verse metre in input.

F/RHYME: rhyme structure in input must be matched by rhyme structure in output.

F/RHYTHM: original rhythm structure must show in target rhythm structure. F/ALIGN: every verse in output must convey the same content as its correspondent verse in original. 
In example 7, we see how F/Metre has been violated. When trying to accommodate a source poem into a target verse tradition results can differ depending on the relative height of "Metre" in the hierarchy. In this example "Metre" is clearly positioned beneath content restrictions (Max and Dep): no content is added, no content is erased. Moreover, "Metre" outranks "F/Metre": the aim is not to carry English metrics into Spanish verse, but to adapt source content into target metrics. Strictly speaking, we are confronted by a new poem with the same contents, the mark of this being the difference in the number of lines. The English ST is based on binary rhythm, mainly the pentameter, while the Spanish translation is based on hendecasyllables and alexandrines, not paying attention to syllable rhythm, but to hemistichs. This is Clara \& Maurice Molho's translation of John Donne's 'A Hymn to God the Father':

(7a) Wilt thou forgive that sin, where I begun,

Which is my sin, though it were done before?

Wilt thou forgive those sinns through which I runn

And doe them still, though still I doe deplore?

When though hast done, thou hast not done,

for I have more. (lines 1-6)

(7b) ¿Querrás tu perdonar aquel pecado

por el que yo empecé y que fue mi pecado, aunque antes que yo lo cometieran?

¿Querrás Tú perdonar aquel pecado a través del que corro y corro siempre,

y siempre lo deploro?

Cuando lo hagas aún no lo habrás hecho, que siempre tengo más. (lines 1-8)

[Will you forgive that sin where I began and which was my sin, though they committed it before me?

Will you forgive that $\sin$ through which I run and always run, and which I always deplore?

When you do, you will still have not for I always have more.]

Beyond differences in content, the following Spanish translation of a Wordsworth sonnet shows how lines are not aligned in correspondence: after the exact alignment of line 5 (word order depending on structural differences in every grammar), "Indian citadel" is split up in the Spanish translation. Although "minster with its tower / substantially expressed" is not exactly mirrored in the syntax and content of "un monasterio irguiendo / 
su torre", what matters here in alignment is that "minster" and "tower" share a line, while "monasterio" and "torre" are kept apart. Both lines 6 and 7 are given a mark $(*)$ in alignment.

(8a) Yet did the glowing west with marvellous power

Salute us; there stood Indian citadel,

Temple of Greece, and minster with its tower

Substantially expressed -a place for bell

Or clock to toll from! [...] ('Composed after a journey across the Hambleton Hills, Yorkshire', lines 5-9)

Pero el oeste ardiente, con poder asombroso nos saludaba: había allí una ciudadela india, un templo de Grecia, un monasterio irguiendo su torre, jun sitio como para que una campana

sonase, o un reloj! [...] (tr. J.M. Valverde, 'Compuesto tras un viaje por Hambleton Hills, Yorkshire’, lines 5-9)

[But the burning west, with amazing power saluted us: there was an Indian citadel there, a temple of Greece, a monastery erecting its tower, a place for a bell

to sound, or a clock!]

\subsection{Markedness constraints}

For each faithfulness constraint there is a markedness constraint claiming for unmarked elements and structures in the target locale (M/CONTENT, M/GRAMMAR, M/VERSE). However it must be underlined that the nature of markedness constraints is not that of diametric opposites to faithfulness constraints; the two can conceivably coincide, although not at all levels. Rather, constraints are active for all textual features, and determine whether these features are provided by replicating ST features, and/or whether the features are aiming to be accepted in the target locale. So, if M/VERSE is dominant, the TT will be written in a verse form conforming to dominant target norms; if M/GRAMMAR is dominant, then the TT will aim for unmarked linguistic structures in the target language; if M/CONTENT is dominant, then referents and content will be unmarked in the TT, conforming to a semantic domestication (such as the recurrent example of translating "Lamb of God" as "Seal of God" for the Inuit).

A case of these restrictions at work can be seen in two translations of the beginning of Hamlet's soliloquy (III.i.56-60), both by Voltaire (1761, in Hermans 1999: 38-9). First the more literal of the two: 
(9a) To be, or not to be, that is the question: Whether 'tis nobler in the mind, to suffer The slings and arrows of outrageous fortune; Or to take arms against a sea of troubles, And by opposing them end them? To die, to sleep,

(9b) Être ou n'être pas, c'est là la question, S'il est plus noble dans l'esprit de souffrir Les piqûres et les flèches de l'affreuse fortune, Ou de prendre les armes contre une mer de trouble, Et en s'opposant à eux, les finir? Mourir, dormir,

[To be or not to be, that is the question, whether it is nobler in the spirit to suffer the jabs and arrows of hideous fortune, Or take arms against a sea of trouble, and by opposing them, end them? To die, to sleep]

All TT verses apart from the fifth are decasyllables, the TT is in blank verse and the primary accents of the original are respected. That, however, violates markedness constraints because this form (blank decasyllables) was not acceptable in mid-eighteenth century French theatre. So, Voltaire proposed a second text:

(9c) Demeure, il faut choisir, et passer à l'instant

De la vie à la mort, et de l'être au néant.

Dieux justes, s'il en est, éclairez mon courage.

Faut-il vieillir courbé sous la main qui m'outrage,

Supporter ou finir mon malheur et mon sort?

[Wait, I must choose, and in an instant pass

from life to death, and from being to nothingness.

Just gods, if you exist, throw light on my courage.

Should I grow old and bend before the hand offending me, Bear or end my misfortune and my fate?]

The rhyming alexandrines satisfy the markedness constraints, but violate the faith constraints regarding metre.

\subsection{Quantities and units}

The problem that optimality theory faces in translation is at first glance the same problem that many other theories face: that of quantities and quantifying. Restrictions restrict something, and that something must be 
identified. Even moving the complications of semantics to one side, something seemingly as simple as textual quantity is problematic when more than one text (for text read 'language', too) is involved. As Pym notes, the matter is 'very complex when we actually set about measuring quantities in different languages. Should we count metrical feet, spoken syllables, written characters, words, ideograms, or what?' (Pym 2004: 88). Metrical feet can clearly be counted, but they are a measure of prosody, not semantics, for example. We see this as a problem with the same root as that of the unit of translation, in that in choosing one basis for the unit above others, we would ignore the complex nature of the interaction of various elements. Pym points to a solution, without developing it in any great depth.

The only solution is to count in whatever measure is pertinent to the specific problem to be solved: inches or centimeters if we are working on layout, seconds and characters if we are subtitling, and so on. Hopefully this distinction will enable us to talk about quantity as a general factor, independently of its measurements. [...] The technical difficulties should not blind us to theoretical importance. (Pym 2004: 88)

Thus with regard to textual quantity we can talk in terms of raw word count and length (or time to be spoken, in the case of a spoken text), with regard to semantic quantity we can talk in terms of different lexemes and their constituents, with regard to metrical quantity we can talk in terms of syllables and/or feet, and so on. Thus quantities at different levels interact with each other, and addition and subtraction are possible at each: and it is this addition and subtraction (or representation and non-representation) that can be seen, and even measured in a certain way, through comparison.

It follows that if the quantity to be measured differs according to the level being compared, then the unit of translation is not a fixed concept, but a multiple and overlapping concept with borders that differ according to context and the translator's priorities. It is primarily syntactic when faithfulness to syntax is high in the hierarchy, semantic when faithfulness to semantics is high, and so on. It is precisely this overlapping that creates points of conflict, and this is where the analyst can discover how such conflict is resolved.

\subsection{Tertium comparationis}

When it comes to textual comparison, in the past many theories have called upon some kind of invariant, or tertium comparationis. Indeed, Toury based his entire method on a tertium comparationis, which he called the Adequate Translation, envisaged as the ST rewritten in a logical language (Toury 1980:116), only to drop the concept in his later work (Toury 1995). The 
problem with the Toury's Adequate Translation, and any form of tertium comparationis based on a logical language, is two-fold: firstly, it assumes the existence of a purely logical language into which all languages can be transferred, and this is far from certain; secondly, it comprises another translation, from the ST into the logical language, and this in turn comprises all of the same problems as the translation of the ST into the TT. For Eco, the problem goes further: if there is a process of translation from the ST into the tertium comparationis, then another tertium comparationis is needed between the ST and the tertium comparationis, and another, and so on ad infinitum (Eco 2003).

We suggest that all these in reality are other possible translations of the ST, which during the process of translation can compete with other texts, until there is a winning candidate. The methodological and theoretical mistake is to award one or another primacy without taking into account context, since ultimately primacy is awarded to the winning candidate. The ideal methodological approach is one that begins with all possible relationships as equals, and then creates a hierarchy of these based on the reality of the case of translation itself.

\subsection{Laws of translation versus faithfulness and markedness}

Toury offers two 'exemplary' laws of translation: the law of growing standardisation and the law of interference. The first is 'one basic law which decades of text-based research into translational products, in many different cultures, have been able to come up with' (Toury 1995: 267) for which Toury offers three definitions.

in translation, source-text textemes tend to be converted into targetlanguage (or target-culture) repertoremes. (Toury 1995: 268)

in translation, textual relations obtaining in the original are often modified, sometimes to the point of being totally ignored, in favour of [more] habitual options offered by a target repertoire. (Toury 1995: 268, square brackets in original)

in translation, items tend to be selected on a level which is lower than the one where textual relations have been established in the source text. (Toury 1995: 269, italics in original)

Pym identifies two more definitions from within Toury's own text of the same law, and states that the law is defined as a 'string of adjectives, instead of staying with just one formulation (of which several good candidates are given)' (Pym 2008: 315), and concludes that this is due to two related factors: the degree of generality of the law (the fact that it can be applied to many textual features and linguistic levels) and the 
indeterminacy of meaning and interpretations. As such, the law is an 'invitation au voyage' (Pym 2008: 315), an invitation to play and experiment with the law itself. This generality is not a problem though: what all three of the definitions above describe a situation where relativelyunmarked structures are chosen in the target text, regardless of what is presented in the source text and regardless of the macro-level. Within our approach, this is a case of markedness constraints at work, placing demands on the textual-linguistic make-up of the target text at all levels. Just as Toury's law is general, so is the concept of markedness: it is not present for just certain structures, but rather potentially for all structures at all levels, whereas specificity arises from individual constraints, and the translator's journey (and interpretation of the source text) from the hierarchy of these.

Toury's law of interference is one that he "has been contemplating for years' (Toury 1995: 274) and is defined as follows: "in translation, phenomena pertaining to the make-up of the source text tend to be transferred to the target text" (Toury 1995: 275). This in itself seems to be stating the obvious, although it is qualified with the observation that this tends to take place 'whether they manifest themselves in the form of negative transfer (i.e. deviations from normal, codified practices of the target system), or in the form of positive transfer (i.e. greater likelihood of selecting features which do exist and are used in any case)' (Toury 1995: 275). Thus Pym's comment of 'Where else is a translation going to get its features from [but the ST]?' (Pym 2008: 315), is more likely to be provocative than naïve: since the target text is a translation, for a different locale, then some element has to come from that locale for it to be recognised by its audience. What Toury identifies corresponds to the Optimality Theory concept of faithfulness, that is that any ST feature potentially can be transferred, but always with a potential cost.

With the two laws corresponding to the concepts of markedness and faithfulness, it is interesting that Pym should posit a case when the two laws interact.

In that case the texteme would be rendered as a texteme, and there would be interference of the negative kind. The translator would not have obeyed the law of growing standardisation; they would have obeyed the law of interference. (Pym 2008: 315)

This would give weight to the argument that a law is representative of constraints: translators can choose whether or not to respect the constraints (or laws). And yet with interaction, a different result is obtained:

However, if the translator opted to render the opposition engraved/penciled, or even law-giver/student, the result could be quite standard in the target culture and yet there would still be interference from the source text. In that case, the translator would 
have acted in accordance with the law of standardisation and the law of interference, both at the same time. (Pym 2008: 315-316)

Just as faithfulness and markedness are not by nature opposed to each other, neither are Toury's laws.

However, if Toury's two exemplary laws are representative of faithfulness and markedness, then what other macro-level laws can there be? Approaching translation in these terms, translation itself is defined by a source-target relationship (faithfulness) and a relationship between the target text and its host surroundings (markedness). According to Optimality Theory, this covers everything at a macro level, and all nuances are created by a combination of faithfulness and markedness at lower levels. So, it is no surprise that the search for further laws has been frustrated, or that Baker's four universals (1996) can be considered as reformulations of Toury's law of interference (Pym 2008: 318-320): Toury's two laws are the only macrolevel laws.

\section{Interaction of constraints: analysis of Shakespeare's sonnet no. 1 in Catalan.}

It is with the analysis of a whole text that we can see the full interaction of constraints, since this is ultimately the principal level with which translators work. As a continuation of the analysis above of sections of a full text, what follows is an analysis of the full versions of Gerard Vergés' and Salvador Oliva's translations of Shakespeare's sonnet number one into Catalan. 
Vergés (1992): M/VERSE $>>$ M/GRAMMAR $>$ F/VERSE $>$ F/GRAMMAR $>>$ F/IDENTITY

\begin{tabular}{|c|c|c|c|c|c|}
\hline Line & F/Identity & F/Grammar & F/Verse & M/Grammar & M/Verse \\
\hline 1 & $\begin{array}{l}* * \text { MAX }(\text { fairest }>\text { belles; we desire }>0 \text { ) } \\
* \text { IDLEX (increase } \neq \text { propaguin) }\end{array}$ & $\begin{array}{l}\text { *ORD (fairest creatures }- \text { increase } \leftrightarrow \\
\text { propaguin }- \text { belles criatures) } \\
\text { *SYN (from fairest creatures }(\mathrm{SN}) \text { we } \\
(\text { Subj.) desire increase } \neq \text { que es propaguin } \\
\text { les belles criatures (Subj.)) }\end{array}$ & $\begin{array}{l}* * \text { RHYTHM }(2 \sigma \\
4 \sigma)\end{array}$ & & \\
\hline 2 & $\begin{array}{l}\text { **MAX (might never die > no mori) } \\
\text { *IDLEX (beauty } \neq \text { encant) }\end{array}$ & *SYN (that thereby $\neq$ perquè) & & & \\
\hline 3 & $\begin{array}{l}* \text { MAX (riper }>\text { madures) } \\
* \text { IDLEX (decease } \neq \text { mustigui) }\end{array}$ & $\begin{array}{l}* * \text { ORD }(\text { riper }- \text { time }- \text { decease } \leftrightarrow \text { temps }- \\
\text { mustigui }- \text { madures) } \\
* * * \text { SYN }(\text { but } \neq \mathrm{i} \text {; by time }(\text { Adv.) } \neq \text { el temps } \\
(\text { Subj.) } \text { riper }(\text { Subj. }) \neq \text { les madures }(\text { Obj.) })\end{array}$ & & & \\
\hline 4 & $\begin{array}{l}\text { *MAX (his memory }>\text { recordatori) } \\
* * \text { IDLEX (heir } \neq \text { fill; memory } \neq \\
\text { recordatori) } \\
* \text { DEP (heir }<\text { fills) }\end{array}$ & $\begin{array}{l}\text { *ORD (heir - bear } \leftrightarrow \text { siguin }- \text { fills) } \\
\text { *SYN (bear his memory }(\text { Obj. }) \neq \text { siguin } \\
\text { recordatori (Pred.)) }\end{array}$ & * RHYTHM $(2 \sigma)$ & $\begin{array}{l}{[e n] \text { siguin }} \\
\text { els tendres } \\
\text { fills } \\
\text { recordatori }\end{array}$ & \\
\hline 5 & $\begin{array}{l}* \text { IDSEM (contracted } \neq \text { enamorat) } \\
* * \text { MAX (own bright eyes }>\text { ulls) }\end{array}$ & $\begin{array}{l}\text { *ORD (contracted - eyes } \leftrightarrow \text { ulls - } \\
\text { enamorat) }\end{array}$ & $\begin{array}{l}* * \text { RHYTHM }(2 \sigma, \\
4 \sigma)\end{array}$ & & \\
\hline 6 & $\begin{array}{l}* \text { MAX (thy light's flame > la teva } \\
\text { llum; substantial >0) } \\
* * \text { IDSEM (fuel } \neq \text { foc; self } \neq \text { teu })\end{array}$ & $*$ SYN (feed'st $\neq$ nodrint) & & & \\
\hline 7 & $\begin{array}{l}\text { *IDSEM (making } \neq \text { mudant) } \\
* \text { IDLEX (famine } \neq \text { escassetat) }\end{array}$ & $\begin{array}{l}* \text { ORD (famine }- \text { abundance } \leftrightarrow \text { abundor }- \\
\text { escassetat) } \\
* * \text { SYN (making } \neq \text { i mudant; making a }\end{array}$ & $\begin{array}{l}* * \text { RHYTHM }(2 \sigma, \\
4 \sigma)\end{array}$ & & \\
\hline
\end{tabular}




\begin{tabular}{|c|c|c|c|c|c|}
\hline & & famine where... $\neq$ mudant l'abundor en...) & & & \\
\hline Line & F/Identity & F/Grammar & F/Verse & M/Grammar & $\mathrm{M} /$ Verse \\
\hline 8 & $\begin{array}{l}* * * \text { MAX (too cruel }>\text { cruel; sweet }>0, \\
\text { self }>0) \\
* * * * \text { DEP }(0>\text { dir; } 0>\text { poc; } 0>\text { ets, } 0> \\
\text { és })\end{array}$ & $\begin{array}{l}* \text { ORD }(\text { foe }- \text { cruel } \leftrightarrow \text { cruel }- \text { enemic }) \\
* * * S Y N(\text { thyself thy foe, to thy sweet self } \\
\text { too cruel } \neq \text { amb tu ets cruel } i \text { dir enemic és } \\
\text { poc; } 0 \neq \text { ets, } 0 \neq \text { és) }\end{array}$ & & & \\
\hline 9 & & & $\begin{array}{l}* * \text { RHYTHM }(2 \sigma, \\
4 \sigma)\end{array}$ & & \\
\hline 11 & $\begin{array}{l}* * \text { MAX (thine own bud }>\text { al teu capoll; } \\
\text { thy content }>\text { el goig) } \\
* \text { DEP (buriest }<\text { has enterrat) } \\
* * \text { IDLEX (content } \neq \text { goig; within } \neq \text { al) }\end{array}$ & $\begin{array}{l}* \text { ORD (bud - buriest }- \text { content } \leftrightarrow \text { goig - } \\
\text { capoll - enterrat) }\end{array}$ & & & \\
\hline 12 & $\begin{array}{l}\text { **MAX (tender churl > avar; in } \\
\text { niggarding }>0) \\
\text { *DEP }(0<\text { la teva bossa) } \\
\text { *IDSEM (mak'st waste } \neq \text { es desdinera) }\end{array}$ & $\begin{array}{l}\text { *SYN (mak'st waste (Subj.: thou) } \neq \text { la teva } \\
\text { bossa (Subj.) es desdinera) }\end{array}$ & & & \\
\hline 13 & *IDLEX (glutton $\neq$ voraç) & $\begin{array}{l}* * \mathrm{SYN} \text { (or else this glutton } b e \neq q u e, \text { si ets } \\
\text { voraç) }\end{array}$ & $\begin{array}{l}* * \text { RHYTHM }(2 \sigma, \\
4 \sigma)\end{array}$ & & \\
\hline 14 & $\begin{array}{l}* * \text { MAX (due }>0, \text { thee }>0 \text { ) } \\
* \text { DEP (to eat }>\text { cruspiràs) } \\
* \text { IDLEX (to eat } \neq \text { cruspiràs) }\end{array}$ & $\begin{array}{l}* \text { ORD (eat }- \text { grave } \leftrightarrow \text { tomba }- \text { cruspiràs) } \\
* \text { SYN (to eat... }(\text { IC }) \neq \text { cruspiràs }(\mathrm{MC}))\end{array}$ & & & \\
\hline & VIOLATIONS: 44 & 25 & 11 & 1 & \\
\hline
\end{tabular}


Oliva (2002): M/GRAMMAR, M/VERSE $>>$ F/GRAMMAR $>$ F/IDENTITY $>>$ F/VERSE

\begin{tabular}{|c|c|c|c|c|c|}
\hline Line & F/Identity & F/Grammar & F/Verse & M/Grammar & M/Verse \\
\hline 1 & $\begin{array}{l}\text { *MAX (fairest > belles) } \\
\text { *IDLEX (desire } \neq \text { volem) }\end{array}$ & & $\begin{array}{l}* \text { METRE } \\
* * \text { RHYTHM }(2 \mathrm{~h} / 2 \sigma \\
4 \sigma)\end{array}$ & & \\
\hline 2 & *IDLEX (rose $\neq$ esplendor) & $\begin{array}{l}* \text { ORD }(\text { rose }- \text { die } \leftrightarrow \text { mori }- \text { rosa) } \\
* \text { SYN (that thereby } \neq \text { perquè; } \\
\text { beauty's rose } \neq \text { l'esplendor de la } \\
\text { rosa) }\end{array}$ & $\begin{array}{l}* \text { METRE } \\
* * \text { RHYTHM }(2 \mathrm{~h} / 2 \sigma \\
4 \sigma)\end{array}$ & & \\
\hline 3 & $\begin{array}{l}* * \text { IDLEX }(\text { riper } \neq \text { més desclosa; } \\
\text { decease } \neq \text { marceixi) }\end{array}$ & $\begin{array}{l}* \text { ORD (riper }- \text { decease } \leftrightarrow \text { marceixi }- \\
\text { més desclosa) } \\
* \text { SYN (should by time decease } \neq \\
\text { marceixi el temps; as } \neq \text { quan) }\end{array}$ & *METRE & & \\
\hline 4 & $\begin{array}{l}\text { *MAX (his tender heir } \neq \text { una tendra } \\
\text { hereva) } \\
\text { **DEP (his tender heir }<\text { vingui una } \\
\text { tendra hereva; bear his memory }<\text { fer- } \\
\text { nos-la present) } \\
\text { *IDSEM (bear his memory } \neq \text { fer-la } \\
\text { present) }\end{array}$ & $\begin{array}{l}\text { *SYN (heir might bear his memory } \neq \\
\text { vingui ... per fer...(Subordinada } \\
\text { adv. final)). }\end{array}$ & $\begin{array}{l}* \text { METRE } \\
* \text { RHYME }\end{array}$ & & \\
\hline 5 & $\begin{array}{l}\text { *MAX (thine own bright eyes }>\text { els } \\
\text { teus ulls radiants) } \\
\text { *IDLEX (contracted } \neq \text { lligat) }\end{array}$ & $\begin{array}{l}\text { *SYN (But thou, contracted } \neq \text { però tu } \\
\text { estàs lligat) }\end{array}$ & $\begin{array}{l}\text { *METRE } \\
* * \text { RHYTHM }(2 \mathrm{~h} / 2 \sigma, \\
4 \sigma)\end{array}$ & & \\
\hline
\end{tabular}




\begin{tabular}{|c|c|c|c|c|c|}
\hline Line & F/Identity & F/Grammar & F/Verse & M/Grammar & M/Verse \\
\hline 6 & $\begin{array}{l}\text { *MAX (light's flame > flama; with } \\
\text { self-substantial fuel > amb la teva } \\
\text { substància) }\end{array}$ & $\begin{array}{l}* * \text { SYN (feed'st thy light's flame } \neq e n \\
\text { nodreixes la flama; self-substantial } \\
\text { (Adj.) fuel } \neq \text { la teva substància }(\mathrm{N} .) \text { ) }\end{array}$ & $n \begin{array}{l}* \text { METRE } \\
* * * * \text { RHYTHM }(1 \mathrm{~h} / \\
2 \sigma, 4 \sigma ; 2 \mathrm{~h} / 2 \sigma, 4 \sigma)\end{array}$ & & \\
\hline 7 & $\begin{array}{l}* * * \text { DEP (making a famine }>\text { vols fer } \\
\text { que hi hagi fam; abundance }<\text { tanta } \\
\text { abundància) } \\
* \text { IDLEX (lies } \neq \text { hi ha) }\end{array}$ & $\begin{array}{l}\text { **SYN (making a famine } \neq \text { fer que } \\
\text { hi hagi fam; where abundance } \\
\text { (Subj.) lies } \neq \text { on hi ha tanta } \\
\text { abundància (Obj.)) }\end{array}$ & $\begin{array}{l}* \text { METRE } \\
* * \text { RHYTHM }(2 \mathrm{~h} / 2 \sigma, \\
4 \sigma) \\
* \text { RHYME }\end{array}$ & & \\
\hline 8 & $\begin{array}{l}\text { *MAX (to thy seet self }>\text { dels teus } \\
\text { encants) } \\
\text { **DEP (thyself thy foe }<\text { tu mateix ets } \\
\text { l'enemic; thyself }<\mathrm{i} \text { tu mateix) } \\
\text { *IDSEM (sweet self } \neq \text { encants) }\end{array}$ & *SYN (thyself $\neq \mathrm{i}$ tu mateix) & \begin{tabular}{|l}
$*$ METRE \\
$*$ RHYME
\end{tabular} & & \\
\hline 9 & $\begin{array}{l}\text { *MAX (the world's fresh ornament }> \\
\text { el més nou de tots els ornaments) } \\
\text { *DEP (the world's fresh ornament < el } \\
\text { més nou de tots els ornaments) } \\
\text { *IDLEX (fresh } \neq \text { nou) }\end{array}$ & $\begin{array}{l}\text { *SyN (thou that art now } \neq \text { ara que } \\
\text { ets) }\end{array}$ & $\begin{array}{l}\text { *METRE } \\
* * \text { RHYTHM }(1 \mathrm{~h} / 2 \sigma, \\
4 \sigma)\end{array}$ & & \\
\hline 10 & $\begin{array}{l}\text { *MAX (and only herald }<\text { i el sol } \\
\text { herald) } \\
\text { *DEP (to the }<\text { d'aquesta) } \\
\text { *IDSEM (gaudy } \neq \text { condícia) }\end{array}$ & $\begin{array}{l}* \text { SYN (gaudy spring } \neq \text { primaveral } \\
\text { condícia) }\end{array}$ & *METRE & & \\
\hline
\end{tabular}




\begin{tabular}{|c|c|c|c|c|c|}
\hline Line & F/Identity & F/Grammar & F/Verse & M/Grammar & M/Verse \\
\hline 11 & $\begin{array}{l}\text { **DEP (mak'st waste < et malgastes, } \\
\text { in niggarding }<\text { en la teva avarícia) }\end{array}$ & *SYN (mak'st waste $\neq$ malgastes) & $\begin{array}{l}* \text { METRE } \\
* \text { ALIGN (v.12) } \\
* * * * \text { RHYTHM }(1 \mathrm{~h} / \\
2 \sigma, 4 \sigma ; 2 \mathrm{~h} / 2 \sigma, 4 \sigma) \\
* \text { RHYME }\end{array}$ & & \\
\hline 12 & $\begin{array}{l}* \text { *MAX (thine own bud }>\text { la flor) } \\
* \text { DEP (thy content }<\text { tot } \text { el poder) } \\
* \text { IDLEX (bud } \neq \text { flor) }\end{array}$ & $\begin{array}{l}* \text { ORD (bud }- \text { buriest } \leftrightarrow \text { enterres - } \\
\text { flor) } \\
\text { *SYN (thy content } \neq \text { el poder que } \\
\text { tens) }\end{array}$ & $\begin{array}{l}\text { *METRE } \\
\text { *ALIGN (v.11) } \\
\text { *RHYME }\end{array}$ & & \\
\hline 13 & $\begin{array}{l}* * \text { MAX (or else }>0 \text {; this glutton }>\text { el } \\
\text { golut) }\end{array}$ & $*$ SYN $(b e \neq$ fes com $)$ & $\begin{array}{l}\text { *METRE } \\
* * \text { RHYTHM }(1 \mathrm{~h} / 2 \sigma, \\
4 \sigma)\end{array}$ & & \\
\hline 14 & $\begin{array}{l}* \text { IDSEM }(\text { thee } \neq \text { ell }) \\
* \text { IDLEX }(\text { due } \neq \text { pertany })\end{array}$ & $\begin{array}{l}* \text { ORD (the grave and thee } \leftrightarrow \text { ell i el } \\
\text { taüt) } \\
* \text { SYN (to eat } \neq \text { que es menja) }\end{array}$ & $\begin{array}{l}* \text { METRE } \\
* * \text { RHYTHM }(2 \mathrm{~h} / 2 \sigma, \\
4 \sigma)\end{array}$ & & \\
\hline & VIOLATIONS: 36 & 19 & 44 & 0 & 0 \\
\hline
\end{tabular}


As we can see from the analysis, Vergés sticks to a more faithful verse scheme (decasyllabic lines), whereas Oliva uses alexandrines, which take into account the greater number of syllables needed to express content in Catalan than in English (since the relatively complex syllable structure of English allows for a greater number of shorter words). As a consequence, Vergés has to omit more elements from his TT to conform to the chosen prosodic structure. In Vergés's text there is also a much greater tendency to stray away from ST syntactic structures, in part for metre and in part for rhyme, whereas Oliva shows a greater tendency to introduce semantic elements not in the ST: this is in part due to the longer lines, but also an indication of a lower ranking of semantic faithfulness. So, faithfulness to semantics is not at the top of the hierarchy.

\section{Conclusions}

It is no surprise that there are so many often conflicting approaches to translation when we analyse the complexity of the activity. The key fault of many past theories was to prioritise transfer on one particular level, which was often semantic, and consider that anything deviating from that was simply wrong. However, with Optimality Theory we have the necessary cognitive framework to explain why no one feature should remain at the top of the hierarchy without reason: there are other forms of faithfulness, rather than simply semantic. What is more, since there is no such thing as a purely faithful output, translation is characterised by the dual relationship of faithfulness and markedness, something already stated by Holmes and Koster. As we see with Oliva, meaning is not something driven purely by the source text. Constraints, then, work at a particular level and across a particular stretch of text, although these stretches and levels overlap. This is where the unit of translation, as a multiple and overlapping concept, lies.

If this is the case, then constraints, or rather recurrent constraint hierarchies, reflect in a certain way Toury's laws. The most general level in Optimality Theory is that of faithfulness and markedness, and these reflect Toury's law of interference (some form of ST presence) and the law of growing standardisation (some form of target locale presence, Toury 1995:267ff.). We believe that the fact that no more laws have been found is not an inherent weakness of the Descriptive Translation Studies programme, but rather because there are no more "macro" laws: it is these and only these that characterise translation in its most basic form. All other laws will in fact be an interaction of the two concepts, and so can be subsumed into them.

Consequently, Optimality Theory does not provide all the answers, but it does provide a framework in which answers can be sought, following the definition of translation as the interaction of faithfulness and markedness. This is why we believe that, just as it can explain Toury's laws (and 
indicate the limitations of the search for laws), Optimality Theory can help to consolidate much work done in translation studies.

\section{Bibliography}

Baker, Mona (1996). "Corpus-based translation studies: The challenges that lie ahead". In Harold Somers (ed.). Terminology, LSP and Translation. Studies in language engineering in honour of Juan C. Sager. Amsterdam: John Benjamins, 175-186.

Bly, Robert (1984). "The eight stages of translation". In William Frawley (ed.). Translation: Literary. Linguistic, and Philosophical Perspectives. Newark: University of Delaware Press, 67-89.

Boersma, Paul, Joost Dekkers \& Jeroen van de Weijer (2000). "Introduction". In Joost Dekkers, Frank van der Leeuw and Jeroen van de Weijer (eds). Optimality Theory: Phonology, Syntax, and Acquisition. Oxford: Oxford University Press, 1-44.

Chesterman, Andrew (1997). Memes of Translation. Amsterdam: John Benjamins.

Chomsky, Noam \& Morris Halle (1968). The Sound Pattern of English. New York: Harper \& Row.

Comrie, Bernard (1989). "Translatability and language universals". Belgian Journal of Linguistics, 4, 53-67.

Eco, Umberto (2003). Dire quasi la stessa cosa. Milan: Bompiani.

Emery, Peter G. (2004). "Translation, equivalence and fidelity. A pragmatic approach". Babel, 50/2, 143-167.

Frank, Armin Paul (1991). "Translating and Translated Poetry: The Producer's and the Historian's Perspectives". In Kitty van Leuven Zwart and Tom Naaijkens (eds). Translation Studies: The State of the Art. Amsterdam: Rodopi, 115-140.

Gutt, Ernst-August (2000). Translation and Relevance: Cognition and Context. Manchester: St Jerome.

Hermans, Theo (1999). Translation in Systems. Manchester: St Jerome.

Holmes, James S. (1988a[1969]). "Poem and Metapoem: Poetry from Dutch to English". In Translated! Papers on Literary Translation and Translation Studies. Amsterdam: Rodopi, 9-22.

Holmes, James S. (1988b[1969]). "Forms of Verse Translation and Translation of Verse Form". In Translated! Papers on Literary Translation and Translation Studies. Amsterdam: Rodopi, 23-33.

House, Juliane (2001). "How do we know when a translation is good?" In Erich Steiner \& Colin Yallop (eds). Exploring Translation and Multilingual Text Production: Beyond Content. Berlin: Mouton de Gruyter, 127-160.

Kager, René (1999). Optimality Theory. Cambridge: Cambridge University Press.

Ke, Ping (1999). "Translatibility vs untranslatibility: a socio-economic perspective". Babel, 45, 289300.

Koster, Cees (2000). An Armamentarium for the Study of Poetic Discourse in Translation. Amsterdam: Rodopi.

Lefevere, André (1975). Translating Poetry: Seven Strategies and a Blueprint. Assen: Van Gorcum.

Levý, Jiri (2000). "Translation as a Decision Process". In Lawrence Venuti (ed.) (2000). The Translation Studies Reader. Abingdon: Routledge, 148-159.

Mason, Ian (1994). "Techniques of translation revisited: a text-linguistic review of 'borrowing' and 'modulation”". In Amparo Hurtado Albir (ed.). Estudis sobre la traducció. Castelló: Publicacions de la Universitat Jaume I, 61-72.

McCarthy, John (2000). Correspondence Theory. Manuscript. Rutgers Optimality Archive. http://roa.rutgers.edu (consulted 13.02.2007).

McCarthy, John (2002). A Thematic Guide to Optimality Theory. Cambridge: Cambridge University Press.

McCarthy, John \& Alan Prince (1993). Generalized Alignment. Manuscript. University ofMassachusetts.

Prince, Alan \& Paul Smolensky (2002[1993]). Optimality Theory. Constraint Interaction in Generative Grammar. Manuscript. Rutgers University and University of Colorado. http://roa.rutgers.edu (consulted 13.02.2007). A revised version of the manuscript was published by Blackwell, Oxford, 2004.

Pym, Anthony (1992). Translation and Text Transfer. An Essay on the Principles of Intercultural Communication. Frankfurt am Main: Peter Lang. 
Pym, Anthony (2004). The Moving Text. Amsterdam: John Benjamins.

Pym, Anthony (2008). "On Toury's laws of how translators translate". In Anthony Pym, Miriam Shlesinger \& Daniel Simeoni (2008). Beyond Descriptive Translation Studies: Investigations in Homage to Gideon Toury. Amsterdam: John Benjamins, 311-328.

Saussure, Ferdinand de (1967). Cours de linguistique générale. Wiesbaden: Otto Harrassowitz.

Song, Jae Jung (2005). "The translatability-universals connection in linguistic typology: Much ado about something", Babel, 51/4, 308-322.

Speas, M. (1997). "Optimality Theory and Syntax: Null Pronouns and Control". In Diane Archangeli and D. Terence Langendoen (eds) Optimality Theory: An Overview. Oxford: Blackwell, 171-199.

Sperber, Dan \& Dierdre Wilson (1995). Relevance. Communication and Cognition. Oxford: Blackwell.

Tirkkonen-Condit, Sonja (2005). "The Monitor Model Revisited: Evidence from Process Research". Meta, 50/2, 405-414.

Toury, Gideon (1980). In search of a theory of translation. Tel Aviv: Porter Institute for Poetics and Semiotics.

Toury, Gideon (1995). Descriptive Translation Studies and Beyond. Amsterdam: John Benjamins.

Vinay, Jean-Paul, and Jean Darbelnet (1958). Stylistique comparée du français et de l'anglais. Paris: Marcel Didier.

APPENDIX: ST AND CATALAN TRANSLATIONS OF SHAKESPEARE'S SONNET NO. 1.

\section{Shakespeare}

From fairest creatures we desire increase,

That thereby beauty's rose might never die,

But as the riper should by time decease,

His tender heir might bear his memory:

But thou, contracted to thine own bright eyes,

Feed'st thy light's flame with self-substantial fuel,

Making a famine where abundance lies,

Thyself thy foe, to thy sweet self too cruel.

Thou that art now the world's fresh ornament

And only herald to the gaudy spring,

Within thine own bud buriest thy content,

And, tender churl, mak'st waste in niggarding.

Pity the world, or else this glutton be,

To eat the world's due, by the grave and thee.

Vergés 1992

Que es propaguin les belles criatures

perquè la rosa de l'encant no mori,

$\mathrm{i}$, quan el temps mustigui les madures, siguin els tendres fills recordatori.

Però tu, dels teus ulls enamorat, 
nodrint la teva llum amb el teu foc i mudant l'abundor en escassetat, amb tu ets cruel, i dir enemic és poc.

Tu, que ets ara del món el fresc ornat i anunci de l'alegre primavera, el goig al teu capoll has enterrat $\mathrm{i}$, avar, la teva bossa es desdinera.

Compadeix-te del món! Que, si ets voraç, junt amb la tomba el món et cruspiràs.

Oliva 2002

De criatures belles, en volem increment perquè no mori mai l'esplendor de la rosa, sinó que, quan marceixi el temps la més desclosa, vingui una tendra hereva per fer-nos-la present.

Però tu estàs lligat als teus ulls radiants, en nodreixes la flama amb la teva substància, vols fer que hi hagi fam on hi ha tanta abundància $i$ tu mateix ets l'enemic dels teus encants.

Ara que ets el més nou de tots els ornaments i el sol herald d'aquesta primaveral condícia, tendre avar, et malgastes en la teva avarícia i enterres dins la flor tot el poder que tens.

Apiada't del món, o fes com el golut que, el que pertany al món, s’ho menja ell i el taüt.

\footnotetext{
${ }^{1}$ Contributions to this article have benefited from the support of Ministerio de Educación y Ciencia (Spain), project number HUM2007-66531 'Análisis traductológico y comparativo de la difusión contemporáneas de Os Lusíadas, de Luiz de Camões, en catalán y castellano'.

${ }^{2}$ Contributions to this article have benefited from the support of a Batista i Roca grant from the Generalitat de Catalunya, for the project 'Anàlisi de traduccions de poesia anglesa al català 19311939 '. Both authors are also grateful to the anonymous reviewers for their comments on how to improve

3 'The hierarchical place of this truth is at the very summit. It is only little by little that one recognizes how many different facts are but ramification, hidden consequences of this truth.' (Saussure 1967:153)

${ }^{4}$ A very useful introductory text for those unfamiliar with Optimality Theory is McCarthy (2002).

${ }^{5}$ See Comrie (1989) for its refusal, and Song (2005) for its permission, both dealing with linguistic universals. Toury (1995) and Chesterman (1997) take a straightforward empiricist view on
} 
translations as cultural objects (a position not easy to defend when facing completely 'covert' translations). Some others see translations as new linguistic shapes for underlying pragmatic facts (Emery 2004) or underlying prelinguistic cognitive realities.

6 'The obstinate presence of the Y [= transferred although not yet translated text] thus makes it difficult to maintain any strong notion of equivalence while translating. This is one of the reasons why individual translators tend not to believe too enthusiastically in equivalence and may indeed privately shun it as an unnecessary falsehood. The basis of comparison is all too available; the translator knows how many alternative TTs [= Target Texts] have been suppressed or could prove superior in the future' (Pym 1992).

7 'Translation is no longer something that can be looked upon as either possible or impossible but it must instead be recognized as "a process in which the perfect or, to be more exact, the optimal solution [...] is (and should be) always pursued by the translator", as can indeed be attested by "the practice of translating and re-translating famous literature throughout the ages" (Ke 1999:296-7)' (Song 2005:310).

8 In fact, the Zukofskys state that 'This translation of Catullus follows the sound, rhythm and syntax of his Latin' (in Lefevere 1975: 19).

${ }^{9}$ Here we use the term 'context' in the same sense as Relevance Theory, i.e. everything that is important in a process.

${ }^{10} 1$ by Morera i Galícia (1922); 2 by Monturiol i Puig (1928); 3 by Triadú (1958);4 by Vergés (1992); 5 and 6 by Oliva (2002).

${ }^{11}$ Examples can be found in close by literary traditions, like in this line of the original Camões's Os Lusíadas translated into Spanish (Gil 1955): «En perigos e guerras esforçados» $\rightarrow$ «n peligros y guerras esforzados».

${ }^{12}$ The terminology and notation is taken from conventions in work on Optimality Theory. F stands for faithfulness (constraint), ID for identity, MAX for realising an input element in the output ('maximising' it), and DEP for a relationship of dependence between output elements and the input.

${ }^{13}$ In some way our F/Content module is a reshaping of Pym's (2004) set of four relationships between quantity and semantic material, i.e., expansion, abbreviation, addition, and deletion. 